\title{
APBN PENDIDIKAN DAN MAHALNYA BIAYA PENDIDIKAN
}

\author{
Oleh: Ridwan Idris ${ }^{*}$
}

\begin{abstract}
The budget of education which has been promoted for an increase would be a reality. The importance of qualified education has been explicitly expressed in the National Constitution, and an increase of educational budget may positively be associated with the quality of education. The remaining problem is the high cost of education particularly for the bottom and middle economic class. Basically, an increase of educational budget would help the community to get access to low cost education easily. Therefore, there must be a political will by the government and the parliament to wisely allocate the budget. In addition, the community and all other stakeholders of educational institutions should control and direct the budget to the right way to achieve qualified education evenly.
\end{abstract}

KEYWORDS: APBN, pendidikan, kebijakan, biaya pendidikan

DALAM sebuah artikel yang dilansir oleh Harian Kompas (22 Januari 2010) menyatakan bahwa indeks pembangunan pendidikan Indonesia meningkat. Indeks Pembangunan Pendidikan atau Education Development Index (EDI) Indonesia berada pada urutan 65 dari 128 negara. Hal ini berada pada tingkat sedang setaraf dengan Malaysia dan Filipina dan di atas dari India, Kamboja, Laos dan Nigeria. ${ }^{1}$

Kenyataan ini perlu disyukuri, akan tetapi tidak boleh dilupakan bahwa masih banyak yang perlu diperbaiki. Menurut Ferdiansyah yang merupakan salah satu anggota Komisi X DPR mengemukakan di harian Kompas (22 Januari 2010) bahwa meskipun berdasarkan data yang dilansir pemerintah menyatakan bahwa pencapaian pendidikan dasar sudah selesai, nyatanya di jalanan kota-kota besar masih banyak anak usia wajib belajar yang tidak berada di bangku sekolah saat jam belajar. ${ }^{2}$ Fakta tersebut bertentangan dengan pernyataan Menteri Pendidikan Nasional yang mengatakan bahwa pendidikan yang dilaksanakan tidak boleh diskri-

*Peraih Magister Pendidikan dalam bidang Majemen Pendidikan dari Universitas Negeri Makassar ini adalah kandidat doktor pada Program Studi Manajemen Pendidikan Universitas Negeri Jakarta. Saat ini ia menjadi dosen tetap Fakultas Tarbiyah dan Keguruan UIN Alauddin Makassar. 
minatif dan pemerintah terus bekerja untuk mengatasi hambatan anakanak belajar dan mendapatkan pendidikan yang berkualitas.

Salah satu penyebab adanya diskriminatif dalam pendidikan adalah masalah biaya pendidikan. Sebagaimana diketahui bahwa biaya pendidikan di Indonesia sangat mahal dan sangat memberatkan masyarakat Indonesia yang kebanyakan masih berada pada taraf ekonomi menengah ke bawah. Sebagai contoh, di kota-kota besar seperti DKI Jakarta rata-rata calon siswa SMA Negeri dibebani iuran peserta didik baru (IPDB) sebesar 3 juta (ada juga yang lebih mahal) selain pungutan yang lain. ${ }^{3}$ Selanjutnya untuk masuk ke perguruan tinggi (PT) akan lebih mahal lagi.

Semua pihak seharusnya memiliki empati pada pendidikan yang merata bagi semua rakyat dan karena itu harus murah dan dapat diakses orang miskin. Semua pihak juga harus mempunya konsep pendidikan untuk mencerdaskan bangsa dan memajukan bangsa, sehingga menghindari komersialisasi pendidikan. Perlu disadari bahwa pendidikan yang tidak merata karena mahalnya pendidikan akan berdampak kepada semua aspek kehidupan bermasyarakat. Pengangguran, kriminalitas dan kemiskinan akan meningkat, sedangkan pertumbuhan ekonomi dan kesehatan akan mengalami kemunduran.

Walaupun perlu disyukuri bahwa pendidikan dasar sembilan tahun akan dapat diakses gratis untuk seluruh masyarakat seperti yang dijanjikan pemerintah. Hal ini sangat dimungkinkan mengingat pemerataan pendidikan menjadi salah satu cita-cita bangsa. Oleh karena itu, berbagai undang-undang disahkan dan dana dialokasikan untuk cita-cita itu. Namun, berbagai pernyataan jaminan negara atas pendidikan itu tidak lebih retorika.

Komitmen pemerintah dalam pembiayaan pendidikan juga dimanifestasikan melalui anggaran pendidikan yang akan meningkat menjadi 20 persen sesuai dengan UU RI Nomor 41/2008. Akan tetapi, meningkatnya anggaran ini masih memiliki banyak hambatan terutama untuk mensinkronkan dengan UU RI tentang Otonomi Daerah dan UU RI tentang BHP. Hasilnya adalah banyak daerah yang menyalahartikan undangundang tersebut seperti yang terjadi di Papua dan Lampung. ${ }^{4}$

Idealnya, meningkatnya anggaran pendidikan akan meningkatkan pemerataan pendidikan. Artinya, seluruh masyarakat dapat menikmati pendidikan baik yang kaya terutama yang miskin, selain itu semua sekolah memiliki sarana yang cukup dan masyarakat dapat menikmati pendidikan yang bermutu. Selanjutnya, dampak yang lebih jauh adalah meningkatkan ekonomi dan kesehatan masyarat, seperti yang diilustrasi-kan oleh Komaruddin Hidayat bahwa Malaysia dan Singapura dapat meningkatkan 
ekonomi masyarakatnya karena pada awalnya meningkat-kan anggaran pendidikannya, akan tetapi hal itu berbeda yang terjadi di Indonesia.

Pertanyaannya yang kemudian muncul adalah apakah yang terjadi dengan anggaran pendidikan ini? Mengapa biaya pendidikan mahal? dan mengapa anggaran pendidikan yang meningkat tidak meningkatkan mutu pendidikan. Masalah-masalah ini akan dikemukakan pada tulisan ini.

\section{ANGGARAN PENDIDIKAN INDONESIA}

Ketersediaan sarana pendidikan yang memadai sangat tergantung oleh besarnya biaya yang diperuntukkan bagi pendidikan per unit, maupun alokasi dana bagi pendidikan dari APBN serta persentase biaya pendidikan dari PDB. ${ }^{5}$ Dengan demikian diperlukan adanya kemauan atau political will dari pemerintah dan para pemegang amanat rakyat (DPR) untuk dapat lebih peduli kepada pendidikan.

Anggaran pendidikan saat ini telah mencapai angka 20 persen dari APBN sesuai dengan UU yang diperjuangkan sedemikian susah. Anggaran ini menurut Jazuli Juwaini berkisar pada angka 213 trilyun rupiah yang akan digunakan untuk membenahi mutu pendidikan dari tingkat sekolah dasar hingga sekolah menengah pertama di seluruh Indonesia. Lebih lanjut Juwaini menyatakan bahwa 60 persen dari dana tersebut akan digunakan untuk mutu dan sarana prasarana pendidikan. ${ }^{6}$

Dengan anggaran yang sedemikian besar sangat diharapkan adanya percepatan pembangunan mutu pendidikan sehingga semua peserta didik mulai dari tingkat dasar sampai perguruan tinggi dapat merasakan pendidikan yang bermutu. Selanjutnya yang tidak kalah pentingnya adalah pemerataan pendidikan bagi seluruh rakyat Indonesia dengan biaya pendidikan yang rendah kalau perlu gratis, tapi mutu tetap didapatkan.

Sebagai masyarakat, kita mungkin sangat mengharapkan pendidikan yang murah tidak menjadikan pendidikan yang murahan seperti yang saat ini terjadi. Faktanya di Indonesia sekolah-sekolah yang bermutu dan dikatakan favorit mewajibkan semua siswanya untuk membayar mahal tak terkecuali bagi sekolah negeri yang merupakan sekolah yang dibangun dari uang rakyat. Sedangkan sekolah-sekolah yang murah bahkan gratis, bukanlah sekolah yang bermutu, bahkan tidak layak disebut sebuah sekolah. Yang lebih menyakitkan, perhatian pemerintah yang ditunggutunggu tidak juga datang sehingga membuat ada kesenjangan antara yang kaya dan miskin dalam memperoleh pendidikan.

Menurut Surakhmad, masyarakat kita sekarang ini terkontaminasi dengan adanya isu pendidikan gratis tapi tidak mengedepankan pendidikan yang bermutu, yang paling penting adalah gratis dulu. Ini merupakan 
hal yang harus dipikirkan, yaitu bagaimana pendidikan gratis tetapi dengan mutu yang lebih baik.7

Pemerintah memang telah menganggarkan dana pendidikan sebanyak 20 persen dari APBN, tapi ketika dunia pendidikan saat ini mulai memasuki era neoliberal pendidikan, dana sebanyak itu menurut sebagian kalangan masih terasa kurang. Kita memang patut sadar bahwa masih banyak sektor-sektor publik lain yang harus diperhatikan oleh negara ketika membuat kebijakan-kebijakan liberalisasi. Meskipun demikian, kebijakan yang dapat mendorong majunya dunia pendidikan harus diprioritaskan oleh pemerintah. Bila tidak, maka dunia pendidikan kita akan terus berada dalam krisis mutu dan krisis kalah saing dari negara-negara berkembang lainnya.

Negara Jerman, Perancis, dan Belanda adalah negara berkembang yang juga menghadapi persoalan yang sama dengan negara Indonesia dalam menyikapi liberalisasi dalam sektor-sektor publik. Namun, di bidang pendidikan mereka tetap memberi subsidi yang memadai. Malaysia misalnya contoh terdekat. Dahulu negara jiran ini yang belajar tentang pendidikan kepada Indonesia dan para tenaga pendidik kita selalu diminta untuk mengajar di sana. Tapi kini realitasnya sungguh terbalik, saat ini kitalah yang menjadikan Malaysia sebagai referensi kemajuan dalam hal pendidikan. Ini disebabkan karena pihak pemerintahan Malaysia memberikan perhatian yang cukup baik bagi kemajuan pendidikannya.

Fakta lain juga menunjukkan keseriusan suatu negara untuk meningkatkan anggaran pendidikan dapat meningkatkan semua sektor yang lain. Menurut Soedijarto negara-negara maju seperti AS, Inggris, Jerman, Perancis dan Jepang, disusul Korea Selatan, Taiwan dan Malaysia adalah negara-negara yang berpegang pada paradigma "to build nation build school". 8

Pada amandemen UUD 1945 pasal 31 dinyatakan dengan tegas bahwa; Ayat (2): "setiap warga negara wajib mengikuti pendidikan dasar dan pemerintah wajib membiayainya". Ayat (4): "negara memprioritaskan anggaran pendidikan sekuarng-kurangnya dua puluh persen dari Anggaran Pendapatan dan Belanja Negara serta dari Anggaran Pendapatan dan Belanja Daerah untuk memenuhi kebutuhan penyelenggaraan pendidikan nasional". Ayat (5): "pemerintah memajukan ilmu pengetahuan dan teknologi dengan menjunjung tinggi nilai-nilai agama dan persatuan bangsa untuk kemajuan peradaban serta kesejahteraan umat manusia". ${ }^{9}$

Amandemen UUD dasar di atas secara tegas menyebutkan setiap warga negara wajib mengikuti pendidikan dasar dan pemerintah wajib membiayainya, akan tetapi kenyataan yang kita lihat masih banyak anak 
usia sekolah dasar yang tidak dapat mengikuti sekolah dasar karena ketidakmampuan dalam biaya pendidikan. Selanjutnya dikatakan bahwa anggaran pendidikan sekurang-kurangnya 20 persen dari APBN dan APBD tapi kenyataannya setelah tiga tahun amandemen itu disetujui dan ditandatangani, baru pada tahun 2010 "mungkin" dapat direalisasikan. Padahal dalam diktum ketetapan tersebut disebutkan bahwa ketetapan ini berlaku sejak tanggal ditetapkan yaitu tahun 2006.

Kemauan dari pemerintah dan anggota DPR dalam sektor pendidikan memang perlu dipertanyakan. Sebagai perbandingan semua negara maju dalam sektor ekonomi, industri, teknologi, ilmu pengetahuan dan lain-lain, telah meletakkan pendidikan sebagai elemen utama dan mengalokasikan anggaran pendidikan yang memadai. Kini rata-rata anggaran pendidikan anggota Uni Eropa adalah 5 persen dari PDB, Belanda 7 persen dari PDB atau 37 persen dari APBN. Di Asia, Indonesia merupakan yang terendah, hanya 1,4 persen dari PDB, sedangkan negara lain, Nigeria 2,4 persen dari PDB, Sri Lanka 3,4 persen dari PDB, India 5,1 persen dari PDB, Malaysia 5,2 persen dari PDB, Brunei 4,4 persen dari PDB, Vietnam 2,8 persen dari PDB, Filipina 3,4 persen dari PDB, Thailand 5,0 persen dari PDB, Korea Selatan 5,3 persen dari PDB dan Jepang 7,0 persen dari PDB. ${ }^{10}$

Banyak alasan sehingga Indonesia terendah dalam mengalokasikan anggaran pendidikan. Yang paling utama adalah dana tidak mencukupi, sektor-sektor lain juga membutuhkan dana sehingga apabila pendidikan diprioritaskan, maka yang lain tidak akan terbangun dan akan menghambat laju perekonomian Indonesia, dan pada akhirnya terimbas pula pada pendidikan.

Pemikiran-pemikiran yang tidak peduli terhadap pendidikan ini perlu dikritisi, sebab pendidikan harus menjadi pilar utama untuk mendorong sektor-sektor lain. Akan sangat mustahil menghasilkan pemikirpemikir dan praktisi-praktisi ekonomi misalnya tanpa pendidikan yang baik. Tenaga-tenaga kesehatan yang handal adalah produk-produk dari pendidikan. Apabila pendidikan tidak ditingkatkan, maka yang terjadi adalah semua sektor akan ketinggalan dengan sendirinya.

Sesuai dengan UUD RI 1945 yang ada, maka pemerintah pusat dan peme-rintah daerah mempunyai kewajiban untuk menyukseskan upaya pe-menuhan hak anak memperoleh pendidikan dengan langkah-langkah antara lain, sebagaimana yang dikemukakan Abdullah sebagai berikut:

1. Menyediakan anggaran yang memadai yang memungkinkan terpenuhi seluruh kebutuhan pendidikan anak usia sekolah dan kebutuhan tenaga pendidik memperoleh penghasilan dan kesejahteraan sosial yang pantas dan memadai.

2. Mengidentifikasi peserta didik yang berprestasi guna pemberian bea- 
siswa dan tenaga pendidik yang berprestasi untuk pemberian insentif.

3. Mengidentifikasi orang tua peserta didik yang tidak mampu ekonominya.

4. Mengintegrasikan program-program pengentasan kemiskinan. ${ }^{11}$

Selanjutnya Abdullah mengemukakan peran DPR dalam upaya memenuhi hak anak untuk memperoleh pendidikan, adalah sebagai berikut:

1. Membuat kebijakan yang mendukung upaya dan program pemerintah untuk melaksanakan UU tentang sisdiknas, utamanya yang terkait dengan hak anak memperoleh pendidikan.

2. Membuat kebijakan yang mendukung dan menentukan porsi APBN yang terkait dengan butir satu.

3. Mengawasi pelaksanaan butir satu dan dua di atas.

4. Memperhatikan dan menyalurkan aspirasi masyarakat, utamanya yang terkait dengan hak anak memperoleh pendidikan.

5. Mengadakan penyelidikan bila dipandang perlu dan atau meminta keterangan pemerintah, utamanya yang terkait dengan masalah hak anak memperoleh pendidikan.

6. Mengusulkan peraturan bila dipandang perlu, utamanya yang terkait dengan hak anak memperoleh pendidikan. ${ }^{12}$

Pernyataan tersebut di atas, mewajibkan kepada pemerintah untuk menjamin terselenggaranya pendidikan yang bermutu bagi setiap warga negara tanpa diskriminasi dan DPR sebagai mitranya. Dengan demikian sangat wajar apabila DPR memperjuangkan terpenuhinya hak anak memperoleh pendidikan dengan mengalokasikan anggaran yang memadai. Kemudian pemerintah sebagai penyelenggara pendidikan seharusnya segera merealisasikan alokasi anggaran sekurang-kurangnya 20 persen kalau bisa lebih di luar gaji guru.

\section{BIAYA PENDIDIKAN YANG MASIH MAHAL}

Kemajuan teknologi mendorong perubahan kehidupan dari sistem agraris menjadi sistem industri sejak beberapa abad lalu (abad 19-20). Sejak saat itu, terjadi pergeseran filsafat hidup dari spiritual menjadi positivismematerialistik. Industrialisasi berkepentingan melipatgandakan produksi barang-barang kebutuhan hidup secara lebih praktis dan pragmatis. Selanjutnya, sistem perindustrian berpengaruh kuat terhadap munculnya sistem politik kekuasaan. Ketika spirit politik kekuasaan bersinergi dengan sifat perindustrian, sistem perekonomian kapitalistik pun mendapatkan keleluasaan. ${ }^{13}$

Dengan filsafat hidup yang demikian manusia akan terdorong untuk 
memunculkan perekonomian kapitalistik dalam semua aktivitas termasuk dalam pendidikan. Pendidikan yang kapitalis yang lebih mementingkan pendapatan dan mengabaikan hak-hak rakyat untuk mendapatkan pendidikan akan memunculkan lembaga-lembaga pendidikan yang komersil. Lembaga-lembaga pendidikan tersebut akan mementingkan kuantitas dan pendapatan lembaga tanpa ada kontrol kualitas keluaran, sehingga pada akhirnya menghasilkan lulusan yang hanya mengejar ijazah untuk menjadi PNS bukan untuk menjadi orang kreatif yang dapat mempekerjakan orang lain.

Dalam kehidupan keseharian kita dalam pendidikan, banyak bermunculan lembaga yang tidak bermutu. Sekalipun ada yang bermutu harus dibayar mahal oleh peserta didik, dan akan memunculkan diskriminasi dalam pendidikan. Yang kaya akan mendapatkan pendidikan yang bermutu sedangkan yang miskin mendapatkan pendidikan yang tidak bermutu bahkan tidak mendapatkan pendidikan sama sekali.

Dalam republik yang demokratis, sebagaimana Indonesia mengklaim diri, kewarganegaraan adalah konsep yang sakral. Warga negara adalah alasan keberadaan negara; paradigma pengelolaan negara berpusat pada warga negara. Konstitusi negara pun dibangun seluruhnya untuk kepentingan warga negara. Semua ini harus tercermin dalam investasi negara untuk warga negara. Salah satu investasi negara yang amat, mungkin paling, penting adalah pendidikan dan betapa pendidikan nasional kita kenyataannya diskriminatif terhadap kelompok paling miskin. Meski tidak intensional, diskriminasi ini sistemik dan dampak negatifnya terhadap masa depan bangsa luar biasa besar.

Menjadi kenyataan yang amat menyedihkan, oleh karena ketiadaan biaya, anak-anak dari kelompok miskin akan terus berguguran di jenjang SD, SMP, dan SMA, tanpa pernah ada kesempatan untuk sampai di perguruan tinggi. Bukan karena mereka tidak mampu secara akademik, tetapi karena mereka tidak mampu membeli kesempatan itu.

Sistem pendidikan nasional kita telah menjadi ajang rebutan orang kaya. Di ajang rebutan orang kaya, anak miskin yang menjadi korban menumpuk amat tinggi. Dampak yang segera terlihat adalah kian sempitnya kemungkinan mobilitas ke atas melalui jalur pendidikan bagi mereka. Selanjutnya, kelompok ini tidak akan mampu mengangkat diri sendiri keluar dari kemiskinan.

Kondisi itu memiliki dampak jangka panjang yang amat luas terhadap survival bangsa ini secara keseluruhan. Kita bisa membayangkan berapa talenta yang mati hanya karena keluarga mereka tidak mampu menanggung beban biaya pendidikan. Tokoh Lintang dalam film/buku 
Laskar Pelangi adalah personifikasi yang baik dari masalah ini. Lintang yang genius harus puas menjadi pengemudi truk karena kemiskinan keluarganya. Lintang bukanlah kasus yang terisolir. Lintang adalah fenomena umum di Indonesia.

Dengan segala upaya dari semua pihak, kecenderungan diskriminatif ini harus berubah. Bila tidak, lupakan saja impian untuk menjadi pemain dalam persaingan global antar bangsa. Sebaliknya, apa yang dikhawatirkan Bung Karno akan terjadi: kita akan menjadi "bangsa kuli dan kuli di antara bangsa-bangsa".

Gejala ke arah sana sudah ada. Indonesia adalah salah satu eksportir buruh dan pembantu rumah tangga terbesar; tenaga kerja Indonesia saat ini sudah menjadi salah satu sumber devisa utama. Membalik arus diskriminasi terhadap kelompok miskin dalam pendidikan nasional kita harus menjadi salah satu key performance indicator dari Kemendiknas. Selain alokasi dana yang adekuat, penghematan sistemik, program yang cerdas, dan tata kelola yang baik di jajaran Diknas, diperlukan untuk mencapainya.

Biaya dalam pendidikan meliputi biaya langsung (direct cost) dan biaya tidak langsung (indirect cost). Biaya langsung terdiri dari biaya-biaya yang dikeluarkan untuk keperluan pelaksanaan pengajaran dan kegiatan belajar siswa berupa pembelian alat-alat pelajaran, sarana belajar, biaya transportasi, gaji guru, baik yang dikeluarkan oleh pemerintah, orang tua, maupun siswa sendiri. Sedangkan biaya tak langsung berupa keuntungan yang hilang (earning forgone) dalam bentuk biaya kesempatan yang hilang (opportunity cost) yang dikorbankan oleh siswa selama belajar. ${ }^{14}$

Biaya-biaya pendidikan yang termaktub di atas, merupakan hal yang harus ditanggung oleh pemerintah dan masyarakat sebagai warga sekolah. Akan tetapi, yang menjadi masalah adalah sering terjadi kebanyakan biaya yang termaktub di atas ditanggung oleh siswa, yang pada akhirnya membuat biaya pendidikan menjadi mahal.

Ada beberapa faktor yang menyebabkan mahalnya biaya pendidikan, yaitu: 1) kurangnya dukungan dan subsidi pemerintah, 2) anggaran pembiayaan sekolah tidak efektif dan efisien, 3) Kurang adanya demokratisasi dan transparansi pengelolaan sekolah, 4) Lemahnya pengawasan dan pengontrolan pungutan biaya sekolah dari pemerintah, 5) Kurangnya kesejahteraan guru, 6) Tidak ada standarisasi biaya operasional sekolah.

\section{Kurangnya Dukungan dan Subsidi Pemerintah}

Pemerintah telah menganggarkan 20 persen dari APBN untuk pendidikan, akan tetapi hal itu belum juga mencukupi karena 20 persen tersebut sudah termasuk dalam gaji dan tunjangan guru. Di sisi lain, kesa- 
daran rendah para pemimpin daerah juga menjadi pemicu mahalnya pendidikan. Otonomi melimpahkan kewenangan dan tanggung jawab besar kepada pemerintah daerah. UU RI tentang BHP, misalnya, memberi kewenangan pemerintah daerah mengatur penyelenggaraan SD, SMP, dan SLTA (Pasal 21). Konsekeunsinya, tanggung jawab pembiayaan yang besar juga harus dipikul pemerintah daerah. Dalam konteks SD-SMP seperti diatur Pasal 41, masih harus ditegaskan berapa yang harus ditanggung pemerintah pusat (60 persen) dan 40 persen pemerintah daerah. Yang jelas, pemerintah daerah juga diwajibkan menanggung minimal $1 / 3$ biaya operasional SLTA. Itu semua adalah ketentuan di atas kertas. Prakteknya, pewujudan tanggung jawab daerah dalam pembiayaan pendidikan amat tergantung komitmen dan niat pemimpin setempat.

\section{Anggaran Pembiayaan Sekolah Tidak Efektif dan Efisien}

Manajemen pembiayaan sekolah bertujuan untuk menjamin ketersediaan biaya penyelenggaraan pendidikan. Setiap tahun sekolah perlu membuat Rencana Anggaran Pendapatan dan Belanja Sekolah (RAPBS) di mana di dalamnya sudah mengalokasikan sumber pembiayaan. Sumbersumber pembiayaan tersebut meliputi; bantuan pemerintah pusat, pemerintah daerah, dana masyarakat, dan sumber lain seperti hibah, usaha sekolah, dan pinjaman sesuai dengan ketentuan yang berlaku. Sekolah yang baik adalah jika persentase penerimaan dana masyarakat dan usaha lainnya lebih besar dari persentase penerimaan bantuan pemerintah. ${ }^{15}$

Efisiensi pendidikan artinya memiliki kaitan antara pendayagunaan sumber-sumber pendidikan yang terbatas sehingga mencapai optimalisasi yang tinggi. Dalam biaya pendidikan, efisiensi hanya akan ditentukan oleh ketepatan di dalam mendayagunakan anggaran pendidikan dengan memberikan prioritas pada faktor-faktor input pendidikan yang dapat memacu pencapaian prestasi belajar siswa. Untuk mengetahui efisiensi biaya pendidikan biasanya digunakan metode analisis keefektifan biaya (cost effectiveness method) yang memperhitungkan besarnya kontribusi setiap masukan pendidikan terhadap efektivitas pencapaian tujuan pendidikan atau prestasi belajar. ${ }^{16}$

Manajemen yang baik dari pihak sekolah dalam mengelola keuangan dan pembiayaan akan meningkatkan ketersediaan anggaran sekolah. Namun sebaliknya, kenyataan yang terjadi di sekolah pada umumnya, apalagi menyangkut keuangan akan sulit sekali diatur. Fakta yang sering terjadi banyak sekolah yang tidak kreatif dalam membuat usaha sekolah untuk meningkatkan keuangan sekolah. Salah satu yang sering terjadi adalah pihak sekolah sangat bergantung pada dana dari masyarakat melalui 
komite sekolah selain yang berasal dari pemerintah pusat/daerah.

Hal yang sering muncul adalah dalam rancangan pembiayaan terdapat sekolah hanya mementingkan rekreasi dan kebutuhan para guru dalam pembiayaan, sehingga rancangan pembiayaan tersebut tidak berhubungan langsung dengan kebutuhan siswa dan pembelajaran. Hal ini membuat anggaran pembiayaan sekolah tidak efektif dan efisien. Mungkin akan lebih baik kalau dana yang ada untuk membiayai alat-alat sekolah seperti media pembelajaran sehingga dana yang ada betul-betul untuk kemajuan pendidikan anak didik. Hal ini akan menekan biaya yang harus ditanggung anak didik.

\section{Kurang adanya demokratisasi dan transparansi pengelolaan sekolah}

Demokratisasi pendidikan merupakan implikasi dari dan sejalan dengan kebijakan mendorong pengelolaan sektor pendidikan dan daerah, yang implementasinya di tingkat sekolah. Berbagai perencanaan pengembangan sekolah, baik rencana pengembangan sarana dan alat, ketenagaan, kurikulum serta berbagai program pembinaan siswa, semua diserahkan pada sekolah untuk merancangnya serta mendiskusikannya dengan mitra horizontalnya dari komite sekolah. ${ }^{17}$

Gagasan demokratisasi ini didasari oleh pertimbangan yang sederhana, yakni memperbesar partisipasi masyarakat dalam pendidikan, tidak sekedar dalam konteks retribusi uang sumbangan pendidikan, tetapi justru dalam pembahasan dan kajian untuk mengidentifikasi berbagai permintaan stakeholder dan user sekolah tentang kompetensi siswa yang akan dihasilkannya. Dengan demikian, diperlukan adanya transparansi dalam pengelolaan.

Sekolah yang mengabaikan demokratisasi dan transparansi dalam pengelolaan sekolah berarti memiliki masalah yang akan ditutupi. Hal yang sering ditutupi biasanya dalam pengelolaan keuangan. Hal inilah yang biasanya memicu adanya persekongkolan dalam keuangan dan akibatnya membebani masyarakat dalam pembiayaan.

\section{Lemahnya pengawasan dan pengontrolan pungutan biaya sekolah dari pemerintah}

Pungutan iuran peserta didik baru (IPDB) atau uang pangkal untuk siswa SMA/SMK negeri seharusnya ditiadakan. Hal tersebut dilakukan karena sangat memberatkan masyarakat selain itu masih banyak terdapat masyarakat yang termasuk dalam kategori miskin. Kalaupun itu dilakukan untuk membantu kelancaran pendidikan dan partisipasi masyarakat terhadap sekolah, seharusnya diawasi dan dikontrol sehingga tidak terlalu 
membebani masyarakat.

Pungutan uang pangkal yang dilakukan oleh seluruh SMA/SMK negeri dalam setiap penerimaan siswa baru (PSB), selain tidak jelas payung hukumnya, juga tidak pernah diaudit. Pengawasan dan pengontrolan dalam hal ini sangat dibutuhkan karena kemungkinan ada beberapa masyarakat yang tidak bisa sekolah karena tidak mampu membayar iuran yang dipungut oleh sekolah. Jelas sekali hal ini memicu biaya sekolah yang mahal.

\section{Kurangnya kesejahteraan guru}

Dalam UU RI tentang Guru dan Dosen ditegaskan bahwa pendidik dan tenaga kependidikan berhak memperoleh penghasilan dan jaminan kesejahteraan sosial yang pantas dan memadai. Namun kenyataannya, banyak guru yang tidak memperoleh kesejahteraan tersebut sesuai dengan undang-undang tersebut. Hal ini akan memicu kurangnya profesional guru dalam melaksanakan tugasnya.

Biasanya yang dilakukan sekolah dalam mensejahterakan gurunya adalah dengan memungut biaya dari siswa untuk membantu keuangan guru, terutama sekali bagi guru yang belum berstatus PNS. Dengan demikian, aturan-aturan seperti ini kembali akan membebani siswa dengan iuran tersebut. Jadi, yang perlu dilakukan adalah memberikan kesejahteraan bagi guru termasuk yang bukan PNS sehingga mereka tidak memungut iuran dari siswa.

\section{Tidak ada standarisasi biaya operasional sekolah}

Kaplan dan Northon menjelaskan ada 2 faktor yang mempengaruhi anggaran yang dinamis yaitu anggaran operasional dan strategi anggaran. Anggaran operasional adalah anggaran yang berhubungan dengan meramalkan pengeluaran penyelenggaraan program baik yang berkaitan dengan manajemen sekolah maupun manajemen pembelajaran. Anggaran strategi memiliki suatu kekuatan inisiatif untuk mengatasi kesenjangan antara keinginan berperilaku kurang baik dan kemauan keras mencapai sesuatu melalui peningkatan yang berkesinambungan. ${ }^{18}$

Kedua anggaran tersebut memerlukan standarisasi sehingga arahnya menjadi jelas dan dapat dipertanggungjawabkan. Tanpa standarisasi anggaran yang jelas akan mengakibatkan pengeluaran anggaran yang tidak bertanggung jawab dan mengakibatkan anggaran yang dikeluarkan tidak efektif apalagi efisien. Oleh karena itu, perlu perencanaan yang jelas terhadap anggaran sehingga dapat ditetapkan standar yang jelas dan me- 
mungkinkan biaya pendidikan dapat lebih murah.

Selain hal-hal yang umum di atas, besarnya biaya belajar para siswa di Indonesia juga disebabkan oleh tiga hal:

Pertama, seragam sekolah, tidak ada anak Indonesia yang mau bersekolah jika mereka tidak memiliki seragam. Bahkan mereka yang bisa bersekolah tanpa seragam pun justru merasa belum menjadi murid sungguhan karena belum punya seragam sekolah. Tanpa disadari, komponen kecil yang satu ini menjadi momok tersendiri bagi para orang tua murid dan murid sekolah di Indonesia. Tak perlu susah memikirkannya seperti apa. Saat anak masuk sekolah pertama kali, kelas satu SD, mereka sudah wajib memiliki seragam. Sekaya apapun anak tersebut, dia tidak boleh menjadi murid di suatu sekolah apabila ia belum memiliki seragam. Kalau anak orang kaya saja tidak boleh bersekolah tanpa seragam apalagi orang miskin.

Tidak sampai di situ saja, membeli seragam sekolah pun tidak bisa cuma sekali. Seiring dengan perkembangan fisik anak, orang tua setiap tahun harus memperbaharui baju sekolah anak mereka. Makin cepat perkembangan fisik seorang anak, makin sering pula orang tua harus membeli seragam baru bagi anaknya. Kemudian biaya ini belum sampai di situ, seragam siswa SD, SMP, dan SMA memiliki perbedaan. Baju seragam putih tapi celananya merah (SD), biru (SMP), dan abu-abu (SMA).

Kedua, beban biaya sekolah juga disebabkan oleh komponen buku pelajaran. Dari dulu sampai sekarang, orang tua murid harus menyediakan sendiri buku pelajaran sekolah bagi anak-anak mereka. Buku apa yang digunakan oleh murid sekolah tergantung dari persetujuan bisnis antara pihak sekolah dan penerbit buku. Seandainya orang tua murid harus membeli buku dari penerbit A dengan harga yang lebih rendah dari harga pasar, maka ini bukan perkara besar. Sayangnya, pengandaian itu selamanya terjadi dalam kenyataan. Tidak jarang harga buku yang dijual di sekolah lebih tinggi daripada harga pasar dan harga toko buku. Ini bisa terjadi karena adanya oknum sekolah yang ingin meraup keuntungan sendiri dan karena penerbit buku harus membayar komisi besar kepada sekolah sehingga mereka membebankan biaya komisi itu pada orang tua murid.

Pengadaan buku secara gratis dengan sistem online oleh Diknas, seperti yang dilakukan tahun lalu, ternyata belum bisa menyelesaikan persoalan mahalnya pengadaan buku. Belum tersediannya fasilitas internet yang menjangkau masyarakat di daerah pedesaan atau terpencil menjadi kendala bagi para murid dan orang tuanya. Pun, seandainya mereka memiliki akses ke internet, biaya pencetakan buku menjadi kendala lainnya. 
Untuk membuat masalah menjadi lebih rumit, Diknas memiliki hobi untuk mengganti-ganti kurikulum nasional sesuka hatinya. Penggantian kurikulum jelas akan berimbas pada buku pelajaran para murid.

Ketiga, biaya-biaya tambahan saat bersekolah menjadi penyebab dari mahalnya bersekolah di Indonesia. Biasanya, pengeluaran rutin orang tua murid untuk biaya sekolah anaknya adalah: 1) iuran sekolah (bulanan, syukurlah kalau tidak pernah naik), 2) seragam, 3) buku pelajaran 4) biaya Study Tour (biasanya cuma sekali, buat SMP dan SMA, dan ini juga tergantung tempat tujuan kunjungannya, makin jauh makin mahal).

Sayangnya, pengeluaran rutin ini menjadi tidak rutin apabila sekolah menambahkan biaya lain yang tidak jelas. Misalnya biaya acara pesta perpisahan untuk murid tingkat akhir. Biaya ini harusnya tidak dibebankan bagi murid kelas satu dan dua. Kalau murid kelas tiga ingin mengadakan pesta perpisahan sendiri, mereka harusnya mengumpulkan uang dari diri mereka sendiri. Contoh biaya tidak jelas lainnya adalah penggalangan dana untuk keperluan yang dibuat-dibuat, seperti, pelepasan pensiun pegawai sekolah, pembelian sarana sekolah, penggalangan dana untuk guru yang sedang berduka atau melahirkan, dan lainnya.

Dari ketiga hal yang sudah disebutkan di atas dapat disimpulkan bahwa menggratiskan biaya sekolah di Indonesia adalah hal yang hampir mustahil. Ini sangat diyakini karena pemerintah Indonesia tidak akan pernah punya uang untuk memberi seragam apalagi memperbaharui seragam sekolah setiap murid di Indonesia. Pemerintah juga tidak akan sanggup memberikan buku-buku gratis apabila kurikulum nasional terlalu sering berganti-ganti, dan yang lebih mustahil adalah membuat anggaran untuk mendanai kegiatan-kegiatan sekolah yang di luar kurikulum dan di luar pembelajaran. Karena itu, setiap usaha untuk menggratiskan biaya bersekolah para murid di negara ini sebaiknya dialihkan pada pencarian cara untuk mengurangi biaya sekolah para murid-murid Indonesia. Sikap ini jauh lebih realistis dan layak untuk diperjuangkan oleh para anggota DPR, staf Kemendiknas, dan seluruh rakyat Indonesia.

Demikian beberapa pernyataan yang mengindikasikan dan menyebabkan biaya pendidikan menjadi mahal. Kemauan atau political will dari pemerintah dan pemegang amanat rakyat untuk memberikan perhatian khusus dalam hal dengan menyediakan anggaran yang memadai. Pengelola pendidikan juga harus lebih fokus dalam mengatur anggaran yang ada sehingga dapat dimanfaatkan dan dipertanggunjawabkan dengan benar. Dengan mengatasi masalah-masalah yang mengakibatkan biaya mahal, maka penyelenggaraan pendidikan dapat lebih diefektifkan dan diefisienkan. 


\section{ANGGARAN PENDIDIKAN TINGGI DAN BIAYA SEKOLAH MAHAL}

Amandemen Pasal 31 UUD 1945 berisi lima ayat yang dengan tegas dan jelas menginstruksikan kepada pemerintah untuk; pertama, membantu putra-putri terbaik bangsa untuk mengikuti pendidikan menengah dan pendidikan tinggi, bukan hanya membebaskan mereka dari membayar SPP, melainkan memberikan beasiswa kepada putra-putri terbaik bangsa di mana pun untuk mengikuti pendidikan menengah dan tinggi.

Kedua, pemerintah harus membiayai sepenuhnya penyelenggaraan pendidikan dasar yang wajib diikuti oleh setiap warga negara usia sekolah. Ini berarti pemerintah tidak hanya membebaskan mereka dari membayar SPP, melainkan juga harus membantu anak usia sekolah memperoleh pendidikan yang bermutu.

Ketiga, pemerintah wajib mengupayakan agar semua sekolah di Indonesia, terutama sekolah yang diselenggarakan oleh pemerintah, dapat diselenggarakan sesuai dengan standar nasional yang ditentukan oleh pemerintah, baik tenaga guru, sarana dan prasarana, kurikulum, proses pembelajaran, serta alat-alat dan media pendidikan terutama buku murid dan buku guru.

Keempat, pemerintah wajib membiayai universitas, terutama negeri, agar dapat berperan menyiapkan sarjana yang bermutu, menghasilkan iptek melalui kegiatan penelitiannya, dan dapat ikut berperan dalam proses pembangunan masyarakat negara dan bangsa sebagai wujud dari upaya melaksanakan tanggung jawab konstitusional sebagaimana tertulis dalam Pasal 31 Ayat (5) UUD RI 1945, yaitu memajukan Iptek. ${ }^{19}$

Kewajiban-kewajiban di atas membutuhkan anggaran yang tidak sedikit. Oleh karena itu, anggaran yang sekarang sudah mencapai 20 persen untuk pendidikan seharusnya digunakan dengan sebaik-baiknya. Dalam hal ini perlu dipahami bahwa anggaran tersebut tidak akan mencukupi apabila tetap disiasati untuk tidak terlalu membebani APBN. Sebagai contoh, anggaran untuk pendidikan tersebut juga diperuntukkan untuk gaji guru dan tunjangannya. Dengan demikian, anggaran yang ada akan tetap tidak mencukupi karena harus dibagi untuk beberapa sektor lain seperti gaji guru tersebut.

Perlu dipahami pula bahwa pemerintah sangat sedikit dalam menganggarkan penelitian. Padahal, pemerintah perlu memahami bahwa penelitian ini sangatlah penting dalam menunjang tercapainya kemajuan ilmu pengetahuan dan teknologi. Sebagai perbandingan, India telah menanggung 89 persen dari kebutuhan dana pendidikan nasionalnya sehingga saat ini telah menikmati kemajuan ipteknya. Demikian pula terhadap negara- 
negara maju yang lain seperti Amerika, China dan sebagian besar negara Eropa. ${ }^{20}$

Selanjutnya Sodijarto menjelaskan secara detail tentang unit cost dalam pendidikan, ${ }^{21}$ yaitu;

Alternatif I
a. Pendidikan Dasar : : Rp58 trilyun
b. Pendidikan Tinggi : : Rp26 trilyun
c. Pendidikan Menengah : Rp16,5 trilyun
d. Pendidikan Prasekolah : Rp 1 trilyun
e. Pendidikan Luar Sekolah : Rp2,5 trilyun
Total
: Rp104 trilyun

Ditambah dana untuk PLB dan pendidikan guru menjadi:

Alternatif II
a. Pendidikan Dasar : : Rp71 trilyun
b. Pendidikan Tinggi : Rp26 trilyun
c. Pendidikan Menengah : Rp16,5 trilyun
d. Pendidikan Prasekolah : Rp 1 trilyun
e. Pendidikan Luar Sekolah : Rp2,5 trilyun
Total
: Rp117 trilyun

Perkiraan perhitungan tentang kebutuhan dana untuk membiayai penyelenggaraan pendidikan nasional yang relevan dan bermutu, yang mencapai Rp107 trilyun sampai Rp117 trilyun, hakikatnya baru merupakan kebutuhan minimum. Dengan dana tersebut sistem pendidikan kita, dalam pengertian sarana dan prasarana, belum dapat memenuhi standar sekolahsekolah di negara tetangga, terutama Singapura dan Malaysia. Namun dengan terpenuhinya kebutuhan minimum tersebut, seluruh anak usia sekolah akan dengan bahagia dapat belajar. Dengan dana sejumlah itu, sekolah-sekolah kita diperkirakan sudah dapat mulai menerapkan empat pilar belajar. Dengan kata lain, lembaga pendidikan kita sudah dapat mulai berfungsi sebagai pusat pembudayaan kemampuan, nilai, dan sikap sebagai bagian dari transformasi budaya menuju masyarakat modern, maju dan demokratis berkeadilan sosial berdasarkan Pancasila dan UUD 1945.22

Sebagaimana dijelaskan sebelumnya bahwa anggaran pendidikan di Indonesia mulai tahun ini akan dianggarkan sesuai dengan amanat UUD 1945 sebesar 20 persen dari APBN. Artinya bahwa, anggaran pendidikan berkisar 213 trilyun. Anggaran yang cukup besar untuk sebuah pembangunan sektor pendidikan apabila dikelola dengan baik.

Pengelolaan anggaran dalam hal ini perlu diperhatikan mengingat Indonesia sebagai sebuah negara besar sangat rentan terhadap penyele- 
wengan anggaran. Apalagi bila tidak dibarengi dengan pengawasan yang berkala dari aparat hukum, maka anggaran yang besar ini tidak akan berjalan dengan efektif dan efisien. Intinya adalah perlu ada pengawasan mulai dari pusat sampai ke daerah.

Selanjutnya, perlu ada tindakan yang serius dari pemerintah untuk mengalokasikan anggaran kepada program-program yang berkaitan langsung dengan proses pembelajaran. Program-program yang tidak sesuai akan mengakibatkan pemborosan anggaran dan membuatnya sia-sia dan tidak bisa dipertanggungjawabkan.

Dari kesemua pernyataan di atas, perlu adanya kemauan keras dari anggota dewan untuk membuat regulasi yang jelas terhadap anggaran yang akan dikeluarkan sehingga betul-betul dapat diproteksi dari hal-hal yang menyimpang. Kemudian pemerintah sebagai penyelenggara perlu memberikan program-program yang jelas terhadap setiap pengeluaran anggaran sehingga dapat terjadi sinkronisasi dari pemerintah dan dewan.

Satu permasalahan yang muncul sekarang adalah dengan anggaran yang besar tadi, masih perlukah pendidikan yang mahal bagi rakyat?. Idealnya dengan anggaran yang besar dari pemerintah untuk pendidikan, maka tidak selayaknya rakyat Indonesia tidak bersekolah hanya karena persoalan biaya. Pendidikan yang mahal dengan berbagai pungutan perlu ditinggalkan.

Pembiayaan sekolah untuk hal-hal yang kurang pas perlu ditiadakan. Program-program yang bisa membebani orang tua siswa perlu segera direvisi. Yang perlu dilakukan sekarang adalah menggunakan anggaran yang ada untuk meningkatkan mutu pendidikan di sekolah. Hal ini sangat tergantung kepada kemauan pimpinan pada sebuah lembaga pendidikan.

Seorang pemimpin yang baik akan lebih mengupayakan sumber dana dari usaha yang poduktif ketimbang harus membebani anak didik dengan biaya terlalu tinggi. Sebagai contoh; program perpisahan, study tour perlu ditinjau ulang untuk diminimalisir, atau program-program tersebut bisa diadakan tapi tidak membebani anak didik dengan pungutan. Pimpinan perlu mencari sumber dana yang lain untuk merealisasikannya.

Dengan penggunaan anggaran yang baik, maka pendidikan mahal tidak akan terjadi lagi. Seperti yang terjadi pada saat ini banyak sekolah yang memungut dana dari masyarakat dengan alasan untuk peningkatan mutu sekolah. Sekolah yang baik adalah sekolah yang dapat menggunakan dana serendah mungkin tapi tetap mempertahankan mutu sekolah.

Sekali lagi perlu adanya kemauan keras dari semua untuk lebih peduli kepada pendidikan. Pemegang amanat rakyat (DPR), pemerintah 
pusat/daerah, kemendiknas, kemenag, kepala sekolah, komite sekolah, guru dan semua masyarakat termasuk di dalamnya. Monitoring implementasi komitmen daerah penting dilakukan. Secara keseluruhan, kembali ke agenda penguatan civil society adalah jalan paling cerdas untuk mencegah rakyat dari ambivalensi politik elit negara dalam mewujudkan pemerataan pendidikan.

\section{PENUTUP}

Sebagai sebuah pilar utama dalam kehidupan bernegara dan berbangsa, pendidikan memiliki peranan penting yang harus segera dibenahi dalam membangun bangsa. Pendidikan menjadi tolak ukur dalam kesejahteraan suatu bangsa. Sektor-sektor lain akan terbengkalai apabila pendidikan tidak dibenahi lebih dulu. Oleh karena itu, pendidikan perlu diberi porsi anggaran yang lebih tinggi untuk memajukan bangsa.

Anggaran pendidikan yang akan menyesuaikan dengan amanat UUD RI 1945 ini perlu dikelola dengan baik. Hal ini penting untuk menghindari biaya pendidikan yang dapat membebani rakyat yang sekarang masih banyak di level ekonomi menengah ke bawah. Anggaran tidak akan efektif seberapa besar pun banyaknya apabila tidak ditangani dengan baik.

Kemauan yang besar dari Pemerintah baik pusat maupun daerah sangat diperlukan. Lepas tanggung jawab dari pemerintah pusat dan daerah perlu ditiadakan dengan menyadari pentingnya sebuah pendidikan bagi sebuah bangsa. Program-program yang terencana dari pimpinan lembaga akan dapat mengefektifkan anggaran yang ada. Selain itu, pengggunaan yang efisien juga harus diperhatikan.

Guru dalam melaksanakan pembelajaran diharapkan menggunakan anggaran dengan produktifitas yang tinggi. Media-media dan alat-alat yang digunakan diharapkan lebih merupakan produk dari guru yang bersangkutan sehingga dana dapat diefisienkan. Sementara masyarakat yang mungkin berlebih dapat lebih banyak berpatisipasi dengan mendukung program pendidikan dengan dana. Pada akhirnya pendidikan yang bermutu dengan biaya yang murah bahkan gratis dapat terwujud.

\section{CATATAN AKHIR}

1. Harian Kompas (22 Januari 2010)

2. Harian Kompas (22 Januari 2010)

3. www.suarakarya-online.com

4. biayapendidikan.com/pemerataan-pendidikan.html 
5. H. A. R. Tilaar, Manajemen Pendidikan Nasional: Kajian Pendidikan Masa Depan, Bandung, PT Remaja Rosdakarya, 2003, h. 151.

6. Harian Kompas (8 Oktober 2009)

7. Winarno Surakhmad, Pendidikan Nasional: Strategi dan Tragedi, Jakarta, PT Kompas Media Nusantara, 2009, h. 163.

8. Soedijarto, Landasan dan Arah Pendidikan Nasional Kita, Jakarta, PT Kompas Media Nusantara, 2008, h. 348.

9. Soedijarto, ibid., h. 352.

10. Soedijarto, ibid., h. 355.

11. Ambo Enre Abdullah, Pendidikan di Era Otonomi Daerah: Gagasan dan Pengalaman, Yogyakarta, Pustaka Timur, 2005, h. 229.

12. Ambo Enre Abdullah, ibid., h. 230.

13. Suparlan Suhartono, Filsafat Pendidikan, Jogjakarta, Ar-Ruzz, 2007, h. 31.

14. Nanang Fattah, Ekonomi dan Pembiayaan Pendidikan, Bandung, PT Remaja Rosdakarya, 2004, h. 23.

15. Arismunandar, Manajemen Pendidikan: Peluang dan Tantangan, Makassar, Badan Penerbit Universitas Negeri Makassar (UNM), 2006, h. 19.

16. Nanang Fattah, op. cit., h. 35.

17. Dede Rosyada, Paradigma Pendidikan Demokrasi: Sebuah Model Pelibatan Masyarakat Dalam Penyelenggaraan Pendidikan, Jakarta, Kencana Prenada Media Group, 2007, h. xii.

18. Syaiful Sagala, Manajemen Stratejik Dalam Peningkatan Mutu Pendidikan, Bandung, Alfabeta, 2007, h. 223.

19. Soedijarto, Landasan dan Arah Pendidikan Nasional Kita, op. cit., h. 369-370.

20. Soedijarto, ibid., h. 371.

21. Soedijarto, ibid., h. 372.

22. Soedijarto, ibid., h. 375 .

\section{DAFTAR PUSTAKA}

Abdullah, Ambo Enre, Pendidikan di Era Otonomi Daerah: Gagasan dan Pengalaman, Yogyakarta, Pustaka Timur, 2005.

Arismunandar, Manajemen Pendidikan: Peluang dan Tantangan, Makassar, Badan Penerbit Universitas Negeri Makassar (UNM), 2006.

Fattah, Nanang, Ekonomi dan Pembiayaan Pendidikan, Bandung, PT Remaja Rosdakarya, 2004.

Harian Kompas (22 Januari 2010)

Harian Kompas (8 Oktober 2009)

Rosyada, Dede, Paradigma Pendidikan Demokrasi: Sebuah Model Pelibatan Masyarakat Dalam Penyelenggaraan Pendidikan, Jakarta, Kencana Prenada Media Group, 2007.

Sagala, Syaiful, Manajemen Stratejik Dalam Peningkatan Mutu Pendidikan, Bandung, Alfabeta, 2007.

Soedijarto, Landasan dan Arah Pendidikan Nasional Kita, Jakarta, PT Kompas Media Nusantara, 2008.

Suhartono, Suparlan, Filsafat Pendidikan, Jogjakarta, Ar-Ruzz, 2007. 
Surakhmad, Winarno, Pendidikan Nasional: Strategi dan Tragedi, Jakarta, PT Kompas Media Nusantara, 2009.

Tilaar, H.A.R, Manajemen Pendidikan Nasional: Kajian Pendidikan Masa Depan, Bandung, PT Remaja Rosdakarya, 2003.

www. biayapendidikan.com/pemerataan-pendidikan.html

www.suarakarya-online.com/ 